\title{
Some Epidemiologic Aspects of Common Warts in Rural Primary School Children
}

\author{
Khaled Kasim, ${ }^{1}$ Soliman Amer, ${ }^{2}$ Mohamed Mosaad, ${ }^{3}$ \\ Alaa Abdel-Wahed, ${ }^{1}$ and Hazem Allam ${ }^{4}$ \\ ${ }^{1}$ Department of Public Health and Community Medicine, Faculty of Medicine, Al-Azhar University, Cairo, Egypt \\ ${ }^{2}$ Department of Public Health and Community Medicine, Damietta Faculty of Medicine, Al-Azhar University, Damietta, Egypt \\ ${ }^{3}$ Department of Infectious and Endemic Diseases, Faculty of Medicine, Suez Canal University, Ismailia, Egypt \\ ${ }^{4}$ Department of Dermatology, Sherbein Central Hospital, Sherbein City, El-Dakhalia, Egypt
}

Correspondence should be addressed to Khaled Kasim; kasimyhr@yahoo.com

Received 6 October 2013; Accepted 6 November 2013

Academic Editors: R. Lindeboom and N. Nassar

Copyright (C) 2013 Khaled Kasim et al. This is an open access article distributed under the Creative Commons Attribution License, which permits unrestricted use, distribution, and reproduction in any medium, provided the original work is properly cited.

\begin{abstract}
Cutaneous warts are common in children worldwide, although the prevalence figures are conflicting. There are few publications on that issue, particularly in rural Egypt. The present cross-sectional study aimed to assess the prevalence of warts of hands in rural primary school children and to examine some risk factors associated with warts in these children. The study examined 1833 children from 15 rural primary schools in Dakahlia governorate, Egypt, for the presence of warts. Data about sociodemographic, lifestyle, and environmental factors were collected. Prevalence of warts was estimated. Appropriate statistical analyses including multivariate logistic regression were done. The prevalence of warts of hands in the studied children was $2.3 \%$ (1.3-3.3\%) with no significant sex difference. The risk of warts increased significantly in children reported swimming in Nile channels (adjusted odds ratio $(O R)=5.6 ; 95 \%$ confidence interval $(C I)=2.9-10.6$ ) and child labor (adjusted $\mathrm{OR}=4.5 ; 95 \% \mathrm{CI}=2.3-8.8$ ). A ninety percent risk reduction was observed in children with educated parents. The study findings demonstrated a significant increase in the risk of warts among rural children reported swimming in Nile channels and child labor. Parents' education, on the other hand, was found to play an important role in risk reduction.
\end{abstract}

\section{Introduction}

Skin diseases are a common cause of morbidity, especially among school children, worldwide [1]. It is considered to be the second most common cause for medical consultation for children in rural communities [2]. Although skin disease is rarely lethal, it can have a significant impact in terms of treatment cost, days absent from school, and psychological distress [1-3]. Verrucae vulgaris (common warts) constitute a common skin problem in children that commonly affect hands and feet. Verrucae are benign epithelial proliferations caused by double stranded DNA virus called human papillomavirus (HPV), of which there are more than 100 different genotypes $[4,5]$.

Cutaneous warts are among the three most common dermatoses in children, and these lesions follow acne and atopic dermatitis in frequency of diagnosis in pediatric dermatology clinics [6]. There have been several studies on the prevalence of cutaneous warts among school children in Egypt and worldwide with the prevalence varying from $2.4 \%$ to $33 \%$ [7-12], with an equal frequency in both sexes. Some of these studies have assessed the risk factors to increase the risk of common warts among children and adolescents. Of these factors, low social class, big family size, and rearing household animals $[8,9]$ were reported. The Egyptian studies in this review, however, were conducted in urban areas in Cairo [11] and Mansoura [12] cities. Currently, there is little information about the epidemiology of warts in rural Egyptian children.

The present cross-sectional study aimed to improve our knowledge about the epidemiology of common warts among rural primary school children in Egypt as a school health problem. The specific objectives of this study were to assess the prevalence of common warts of hands in primary school children in rural communities and to examine the possible 
TABLE 1: Characteristics of the studied children by their sociodemographic factors and warts.

\begin{tabular}{|c|c|c|c|}
\hline Characteristics $^{*}$ & Warts $(n=42)$ & No warts $(n=1791)$ & $P$ value \\
\hline Age $($ mean $\pm \mathrm{SD})$ & $11.6 \pm 0.33$ & $11.7 \pm 0.34$ & 0.85 \\
\hline Sex & & & 0.80 \\
\hline Male & $22(52.0)$ & $904(50.5)$ & \\
\hline Female & $20(48.0)$ & $887(49.5)$ & \\
\hline Family size & & & $0.03^{* *}$ \\
\hline$\leq 5$ & $16(38.0)$ & $980(55.0)$ & \\
\hline$>5$ & $26(62.0)$ & $811(45.0)$ & \\
\hline Father's education & & & $0.0001^{* *}$ \\
\hline Illiterate & $5(12.0)$ & $78(4.0)$ & \\
\hline Less than 2ry school & $31(74.0)$ & $908(51.0)$ & \\
\hline Secondary school and higher & $6(14.0)$ & $805(45.0)$ & \\
\hline Mother's education & & & $0.0001^{* *}$ \\
\hline Illiterate & $8(19.0)$ & $110(6.0)$ & \\
\hline Less than 2ry school & $29(69.0)$ & $958(54.0)$ & \\
\hline 2ry school and higher & $5(12.0)$ & $723(40.0)$ & \\
\hline Father's occupation & & & 0.66 \\
\hline Nonskilled work & $8(19.0)$ & $253(14.0)$ & \\
\hline Skilled work & $29(69.0)$ & $1323(74.0)$ & \\
\hline Professional work & $5(12.0)$ & $215(12.0)$ & \\
\hline Mother's occupation & & & $0.0001^{* *}$ \\
\hline Housewife & $33(78.0)$ & $1454(80.7)$ & \\
\hline Skilled work & $7(17.0)$ & $221(12.3)$ & \\
\hline Professional work & $2(5.0)$ & $116(7.0)$ & \\
\hline
\end{tabular}

${ }^{*}$ Data are presented by mean \pm SD or $n(\%)$.

** Significant.

risk factors associated with the development of warts in these children.

\section{Subjects and Methods}

The present study recruited 6th grade primary school children from El-Dakahlia governorate, Delta region, Egypt, to determine the prevalence of common warts of hand among them and to examine the possible associated risk factors. A multistage random sampling technique was used to select the studied children from all rural primary schools in the governorate. The sample size was calculated according to the average prevalence of Verruca vulgaris in urban school children (5\%) reported in previous Egyptian studies [11, 12] and to an assumed precision of 0.01 with confidence interval of $95 \%$ and probability value of 0.05 .

All children were eligible, and no exclusion criteria were used. The children were interviewed and examined individually in the classroom where the school nurse, doctor and/or the class teacher were attending. A child was diagnosed to have a Verruca vulgaris (common wart) in presence of a sessile, firm, variable sized papule, with rough papillary surface, skin colored or darker $[13,14]$. Out of 1870 children interviewed in 15 rural primary schools in the studied governorate, 1833 agreed to participate (98\% response rate). Those who refused to participate did not differ significantly from those participated regarding sociodemographic characteristics.
Based on review of the literature, a questionnaire was designed to collect relevant data from the studied children to investigate possible risk factors of warts. The questionnaire included questions about (i) sociodemographic factors: age, sex, family size, and parents' education and occupation; (ii) lifestyle factors: swimming, sport practice, and working after school time (child labor); and (iii) environmental factors: presence of household animals (farm, pet, and domestic birds). The validity of the used questionnaire was obtained from discussions with a dermatologist, an infectious disease consultant, and two community medicine consultants.

All data analyses were performed by using statistical analysis system software package [15]. In order to compare the distribution of the studied factors in diseased and nondiseased children, $\chi^{2}$ tests for the categorical variables and $t$ test for the continuous variables were used. The level of statistical significance was defined as $P \leq 0.05$. Multivariate logistic regression analyses were used to estimate odds ratios (OR) and their 95\% confidence intervals (95\% CI) for the association of sociodemographic, lifestyle, and environmental factors with the risk of common warts in the studied children. The school officials were clearly informed about the aim and scope of the research. No one of the studied children was obliged to participate in the study. Furthermore, ethical consideration were considered to avoid physical or emotional harm and to ensure confidentiality and privacy of the collected data. 
TABLE 2: Distribution of the studied children by lifestyle and environmental factors according to warts.

\begin{tabular}{|c|c|c|c|}
\hline Lifestyle factor & Warts $(n=42)$ & No warts $(n=1791)$ & $P$ value \\
\hline Swimming in Nile channels & & & $0.0001^{*}$ \\
\hline No & $22(52.0)$ & $1520(85.0)$ & \\
\hline Yes & $20(48.0)$ & $271(15.0)$ & \\
\hline Child labor & & & $0.0001^{*}$ \\
\hline No & $21(50.0)$ & $1402(94.0)$ & \\
\hline Yes & $21(50.0)$ & $389(6.0)$ & \\
\hline Regular sport practice & & & 0.88 \\
\hline No & $22(52.0)$ & $988(55.0)$ & \\
\hline Yes & $20(48.0)$ & $803(45.0)$ & \\
\hline Farm animals & & & $0.002^{*}$ \\
\hline No & $9(21.0)$ & $547(31.0)$ & \\
\hline Yes & $33(79.0)$ & $1244(69.0)$ & \\
\hline Pet animals & & & $0.002^{*}$ \\
\hline No & $8(19.0)$ & $458(26.0)$ & \\
\hline Yes & $34(81.0)$ & $1333(74.0)$ & \\
\hline Domestic birds & & & 0.47 \\
\hline No & $2(5.0)$ & $158(9.0)$ & \\
\hline Yes & $40(95.0)$ & $1633(91.0)$ & \\
\hline
\end{tabular}

*Significant.

\section{Results}

The prevalence of wart of hand in the studied children was $2.3 \%(95 \% \mathrm{CI}=1.3-3.3)$, with no statistically significant difference by sex. The prevalence was $2.4 \%$ and $2.2 \%$ in male and female children, respectively. Table 1 presents the sociodemographic characteristics of the studied sample by wart. There were no statistically significant differences between the mean age and sex distribution among the studied children with and without warts. There have been differences between children with warts and without warts regarding their parents' education and occupation. The lower percent of education and professional work was among children with warts. Also, children reporting they came from a large family showed a higher prevalence of warts with statistically significant difference.

Table 2 displays the distribution of the studied children by lifestyle and environmental factors by warts. There were significant differences between children with and without warts regarding swimming in Nile channels and working after school time (child labor) $(P=0.0001)$. Also, there were significant differences between diseased and nondiseased children with regard to the presence of farm and pet animals. On the other hand, no significant difference was observed between both groups regarding regular sport practice (football practice).

Table 3 presents the adjusted odds ratios and their 95\% confidence intervals for the association of warts with the studied sociodemographic factors. Sex of children appeared to have no role in the risk of warts with an adjusted OR of 0.96 $(\mathrm{CI}=0.50-1.70)$. The risk of warts, however, showed a twofold risk in children with a reported family size more than five. Parents' education and occupation of the studied children appeared to have an important role in the risk of warts where the risk was markedly reduced among children with educated and professional worker parents. The risk was reduced by about $90 \%$ in those children with educated parents.

Table 4 shows the adjusted odds ratios and their 95\% confidence intervals for the association of warts with the studied lifestyle and environmental factors by residence. The risk of warts was significantly increased in association with child labor $(\mathrm{OR}=4.5$; $\mathrm{CI}=2.3-8.8)$. Similarly, swimming in Nile channels was associated with a significant increased risk with an adjusted OR of 5.6 $(\mathrm{CI}=2.9-10.6)$. The presence of household animals was associated with a nonsignificant increased risk of warts. The risk was 1.6, 1.7, and 1.9 in children who reported rearing farm animals, pet animals, and domestic birds, respectively. Regular sport practice, however, appeared to have a minimal role in the risk of warts in the studied children.

\section{Discussion}

The present study revealed the prevalence of common warts of hands in the studied children to be $2.3 \%$. A similar prevalence of warts in primary school children was also reported in different studies conducted in Mansoura city, Egypt [12], Taiwan [7], and Romania [16]. The prevalence in these studies was $2.5 \%, 2.4 \%$, and $2.8 \%$, respectively.

A higher prevalence rate, however, was reported in an Egyptian study conducted in Bab El-Sharia region, Cairo, Egypt [11], and in a regional study conducted in Saudi Arabia, in Al Hassa rural area [17]. The prevalence rate in these two studies was $7.5 \%$ and $4.5 \%$, respectively. Primary school children of all grades were included in these studies, and their estimated prevalence included common warts of both hands and feet. The high prevalence rate observed in these 
TABLE 3: Adjusted odds ratios (ORs) and 95\% confidence intervals (CIs) for the association of warts with the studied sociodemographic factors.

\begin{tabular}{|c|c|c|c|}
\hline Factor & Warts $(n=42)$ & No warts $(n=1791)$ & $\mathrm{OR}^{*}(95 \% \mathrm{CI})$ \\
\hline \multicolumn{4}{|l|}{$\operatorname{Sex}^{*}$} \\
\hline Female & 22 & 904 & 1.0 (Ref.) \\
\hline Male & 20 & 887 & $0.96(0.50-1.70)$ \\
\hline \multicolumn{4}{|l|}{ Family income* } \\
\hline$\leq 5$ & 16 & 980 & 1.0 (Ref.) \\
\hline$>5$ & 26 & 811 & $1.8(0.80-4.30)$ \\
\hline \multicolumn{4}{|l|}{ Father's education* } \\
\hline Illiterate & 5 & 78 & 1.0 (Ref.) \\
\hline Less than 2ry school & 31 & 908 & $0.49(0.15-0.89)$ \\
\hline 2ry school and higher & 6 & 805 & $0.11(0.04-0.39)$ \\
\hline \multicolumn{4}{|l|}{ Mother's education* } \\
\hline Illiterate & 8 & 110 & 1.0 (Ref.) \\
\hline Less than 2ry school & 29 & 958 & $0.43(0.10-0.42)$ \\
\hline 2ry school and higher & 5 & 723 & $0.10(0.03-0.30)$ \\
\hline \multicolumn{4}{|l|}{ Father's occupation* ${ }^{*}$} \\
\hline Nonskilled worker & 8 & 253 & 1.0 (Ref.) \\
\hline Skilled worker & 29 & 1323 & $0.72(0.32-1.6)$ \\
\hline Professional worker & 5 & 215 & $0.75(0.24-2.3)$ \\
\hline \multicolumn{4}{|l|}{ Mother's occupation } \\
\hline Housewife & 33 & 1454 & 1.0 (Ref.) \\
\hline Skilled worker & 7 & 221 & $1.4(0.62-3.3)$ \\
\hline Professional worker & 2 & 116 & $0.75(0.19-3.2)$ \\
\hline
\end{tabular}

* OR was adjusted by swimming in Nile channels, child labor, sport practice, and presence of household animals.

TABLE 4: Odds ratios (ORs) and 95\% confidence intervals (CIs) for the association of warts with the studied lifestyle and environmental factors.

\begin{tabular}{|c|c|c|c|}
\hline Factor & Warts $(n=42)$ & No warts $(n=1791)$ & $\mathrm{OR}^{*}(95 \% \mathrm{CI})$ \\
\hline \multicolumn{4}{|c|}{ Swimming in Nile channels ${ }^{*}$} \\
\hline No & 22 & 1520 & 1.0 (Ref.) \\
\hline Yes & 20 & 271 & $5.6(2.9-10.6)$ \\
\hline \multicolumn{4}{|c|}{ Child labor* } \\
\hline No & 21 & 1402 & 1.0 (Ref.) \\
\hline Yes & 21 & 389 & $4.5(2.3-8.8)$ \\
\hline \multicolumn{4}{|c|}{ Regular sport practice* } \\
\hline No & 22 & 988 & 1.0 (Ref.) \\
\hline Yes & 20 & 803 & $1.20(0.60-4.2)$ \\
\hline \multicolumn{4}{|c|}{ Farm animals* } \\
\hline No & 9 & 547 & 1.0 (Ref.) \\
\hline Yes & 33 & 1244 & $1.6(0.75-3.3)$ \\
\hline \multicolumn{4}{|c|}{ Pet animals ${ }^{*}$} \\
\hline No & 8 & 458 & 1.0 (Ref.) \\
\hline Yes & 34 & 1333 & $1.7(0.67-3.2)$ \\
\hline \multicolumn{4}{|c|}{ Domestic birds } \\
\hline No & 2 & 158 & 1.0 (Ref.) \\
\hline Yes & 40 & 1633 & $1.9(0.50-8.1)$ \\
\hline
\end{tabular}

${ }^{*}$ OR was adjusted by sex, family income, and parents' education and occupation. 
and other studies may reflect the availability of school health care services. Availability of health care services in schools may help an early diagnosis and prompt treatment of diseased children [18], which in turn shortens disease duration, and decreases its prevalence [19].

The prevalence of warts in the present study was not affected by sex of the studied children with an odds ratio close to the null. This finding appeared consistent with the results of several previous studies conducted in different countries, including Egypt [7-12].

The risk of warts in this study was found to increase significantly in children who reported swimming in Nile channels with an adjusted OR of $5.6(95 \% \mathrm{CI}=2.9-10.6)$. It is generally accepted that HPV infection via the environment is more likely to occur if the skin is macerated and in contact with roughened surfaces, the conditions which are common in swimming and communal washing areas [20, 21]. The study findings revealed a significant increase in the risk of warts in association with child labor, with an adjusted odds ratio of $4.5(95 \% \mathrm{CI}=2.3-8.8)$. Child labor is highly relevant to the socioeconomic status of the family which in turn affects the incidence and prevalence of warts $[7,9]$. The presence of household animals was also associated with a nonsignificant increased risk of warts in the studied children. The estimated risk was $1.6(95 \% \mathrm{CI}=0.75-3.3)$ for farm animals, 1.7 (95\% $\mathrm{CI}=0.67-3.2)$ for pet animals, and $1.9(95 \% \mathrm{CI}=0.50-8.1)$ for domestic birds. These findings coincide with the results of previous studies $[8,9]$ and confirm the well-settled role of environmental factors profoundly influence the occurrence of warts [20,21]. Presence of household animals is a feature of rural communities in Egypt which contributes to poor standards of hygiene favoring spread of contagious skin diseases.

Regular sport practice, however, appeared to have a minimal role in the risk of warts development in the studied children. The OR for the association of sport practice with warts was $1.20(95 \% \mathrm{CI}=0.60-4.2)$, and this finding appeared consistent with the study results of van Haalen et al. [8]. Family size has also been associated with an increased risk of warts in children in families with more than five members, although not significant. Similarly, the risk of warts is increased in children with a family member with warts [8] and in children with large families and low social class $[8,9]$. Large families, particularly in rural areas, usually experience overcrowding and poor personal hygiene such as shared clothing and fomite [8]. These factors may increase the risk of infectious skin diseases.

The study findings revealed a significant and marked risk reduction in children with higher educated parents. In these children, the risk is reduced by $90 \%$. Also, the risk of warts is reduced by $25 \%$ in children with professional worker parents, although not significant. These findings coincide with the results of a cross-sectional study carried out in Magong, Taiwan, and included 3273 children aged 6-11 years [9]. In this study, the authors reported that having a father with a manual occupation was associated with an increased risk for having cutaneous warts. Education and occupation of the individuals certainly affect health awareness and standards of hygiene within the family; for example, an educated parent will seek medical help if his son has wart $[22,23]$. Although this attitude is less likely to decrease wart incidence, it may decrease wart prevalence through shortening disease duration [19].

The present study appeared to have a number of strengths that include being a school based study, the matter which consolidates the study findings. The sample was relatively large in size with a high response rate of interviewed children in the studied 15 schools. The study questionnaire was comprehensive and included most of the possible risk factors associated with the development of warts.

Limitations of this study should not also be overlooked. The study reported only the warts of hands in the studied children and warts in other body sites were not reported. The role of age as a risk factor in development of warts could not be assessed in this study due to the narrow range of age in the study sample. Also, the per capita income of the child's family could not be assessed in this young age through the questionnaire. However, the data collected about the children parents' education, occupation, and family size might reflect the per capita income in this study.

In summary, the present study found the prevalence of warts in rural primary school children to be $2.3 \%$ with no significant sex difference. The main risk factors implicated in the development of warts in these children were swimming in Nile channels, child labor, presence of household animals, and big family size. On the other hand, however, warts seemed to be less common in children with educated parents.

\section{Acknowledgments}

The authors would like to thank all the primary school children who participated in this study. They also acknowledge the doctors, nurses, teachers, and officials of all the visited schools for their help and cooperation.

\section{References}

[1] M. W. Greaves, "Dermatology," Practitioner, vol. 217, no. 1300, pp. 585-590, 1976.

[2] J. I. Figueroa, T. Hawranek, A. Abraha, and R. J. Hay, "Prevalence of skin diseases in school children in rural and urban communities in the Illubabor province, south-western Ethiopia: a preliminary survey," Journal of the European Academy of Dermatology and Venereology, vol. 9, no. 2, pp. 142-148, 1997.

[3] A. Varela, A. M. Tremaine, A. Gewirtzman et al., "Common viral infections, human papillomavirus," in Skin Infections Diagnosis and Treatment, J. C. Hall and B. J. Hall, Eds., pp. 2341, Cambridge University Press, New York, NY, USA, 2009.

[4] E.-M. de Villiers, C. Fauquet, T. R. Broker, H.-U. Bernard, and H. Zur Hausen, "Classification of papillomaviruses," Virology, vol. 324, no. 1, pp. 17-27, 2004.

[5] S. Gibbs, I. Harvey, J. Sterling, and R. Stark, "Local treatments for cutaneous warts: systematic review," British Medical Journal, vol. 325, no. 7362, pp. 461-464, 2002.

[6] N. B. Silverberg, "Human papillomavirus infections in children," in Pediatric Infectious Diseases Revisited, H. Schroten 
and S. Wirth, Eds., pp. 365-390, Birkhäuser, Basel, Switzerland, 2007.

[7] Y.-C. Yang, Y.-W. Cheng, C.-S. Lai, and W. Chen, "Prevalence of childhood acne, ephelides, warts, atopic dermatitis, psoriasis, alopecia areata and keloid in Kaohsiung County, Taiwan: a community-based clinical survey," Journal of the European Academy of Dermatology and Venereology, vol. 21, no. 5, pp. 643649, 2007.

[8] F. M. van Haalen, S. C. Bruggink, J. Gussekloo, W. J. J. Assendelft, and J. A. H. Eekhof, "Warts in primary schoolchildren: Prevalence and relation with environmental factors," British Journal of Dermatology, vol. 161, no. 1, pp. 148-152, 2009.

[9] G.-Y. Chen, Y.-W. Cheng, C.-Y. Wang et al., "Prevalence of skin diseases among schoolchildren in Magong, Penghu, Taiwan: a community-based clinical survey," Journal of the Formosan Medical Association, vol. 107, no. 1, pp. 21-29, 2008.

[10] M. Kilkenny, K. Merlin, R. Young, and R. Marks, "The prevalence of common skin conditions in Australian school students: common, plane and plantar viral warts," British Journal of Dermatology, vol. 138, no. 5, pp. 840-845, 1998.

[11] N. N. Makhlouf, The prevalence of dermatological diseases among school children in Bab El-Shaareya region, Cairo city [M.S. thesis of dermatology and venereology], Faculty of Medicine, Al-Azhar University, 2007.

[12] H. Fathy, S. El-Mongy, N. I. Baker, Z. Abdel-Azim, and A. ElGilany, "Prevalence of skin diseases among students with disabilities in Mansoura, Egypt," Eastern Mediterranean Health Journal, vol. 10, no. 3, pp. 416-424, 2004.

[13] R. Kirnbauer, P. Lenz, and M. M. Okun, "Human papillomavirus," in Dermatology, J. L. Bolognia, J. L. Jorizzo, and R. P. Rapini, Eds., pp. 1183-1198, Mosby, London, UK, 2nd edition, 2008.

[14] J. C. Sterling, "Virus infections, human papillomaviruses," in Rook's Textbook of Dermatology, T. Burns, S. Breathnach, N. Cox, and C. Griffiths, Eds., vol. 2, pp. 37-60, Blackwell Science, Oxford, UK, 8th edition, 2010.

[15] SAS Institute, Propriety Software Release 8. 2., SAS Institute, Cary, NC, USA, 1999.

[16] R. Popescu, C. M. Popescu, H. C. Williams, and D. Forsea, "The prevalence of skin conditions in Romanian school children," British Journal of Dermatology, vol. 140, no. 5, pp. 891-896, 1999.

[17] T. T. Amin, A. Ali, and F. Kaliyadan, "Skin disorders among male primary school children in Al Hassa, Saudi Arabia: prevalence and socio-demographic correlates-a comparison of urban and rural populations," Rural and Remote Health, vol. 11, no. 1, article 1517, 2011.

[18] R. B. Wallace, "Epidemiology and public health," in MaxcyRosenau-Last Public Health \& Preventive Medicine, R. B. Wallace, N. Kohatsu, and J. M. Last, Eds., pp. 5-26, McGraw-Hill, New York, NY, USA, 15th edition, 2008.

[19] K. J. Rothman and S. Greenland, "Measures of occurrence," in Modern Epidemiology, K. J. Rothman S Greenland and T. L. Lash, Eds., pp. 32-50, Lippincott Williams \& Wilkins, Philadelphia, Pa, USA, 3rd edition, 2008.

[20] S. Gibbs, "Local treatments for cutaneous warts," in EvidenceBased Dermatology, H. Williams, M. Bigby, T. Diepgen, A. Herxheimer, L. Naldi, and B. Rzany, Eds., pp. 347-353, Blackwell, Malden, Mass, USA, 2nd edition, 2008.

[21] J. C. Sterling, S. Handfield-Jones, and P. M. Hudson, "British Association of Dermatologists. Guidelines for the management of cutaneous warts," British Journal of Dermatology, vol. 144, no. 1, pp. 4-11, 2001.
[22] S. H. Cochrane, J. Leslie, and D. J. O’Hara, "Parental education and child health: intracountry evidence," Health Policy, vol. 2, no. 3-4, pp. 213-250, 1982.

[23] Y. S. Chou, J. T. Liu, M. Grossman, and T. Joyce, "Parental education and child health: evidence from a natural experiment in Taiwan," American Economic Journal, Applied Economics, vol. 2, no. 1, pp. 33-61, 2010. 


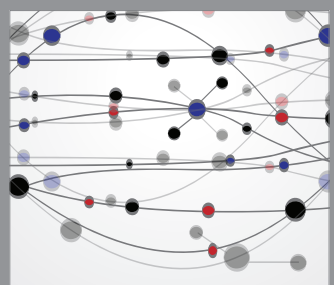

The Scientific World Journal
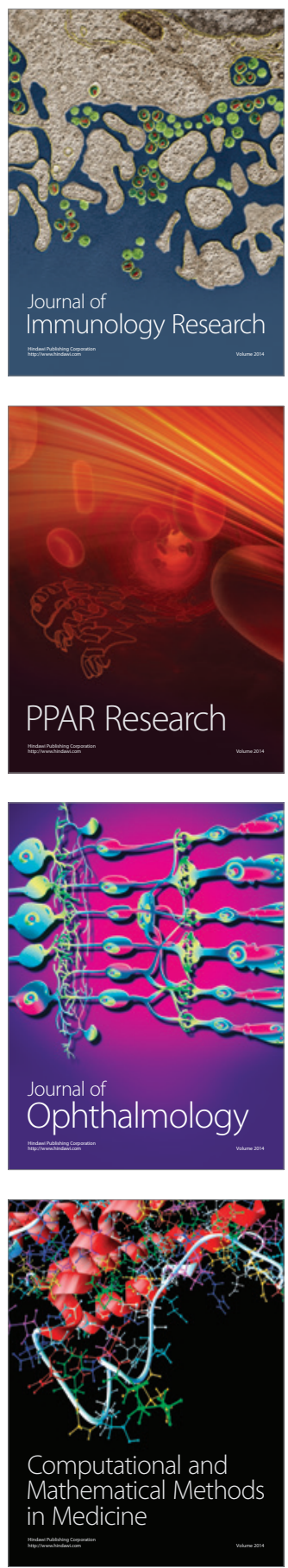

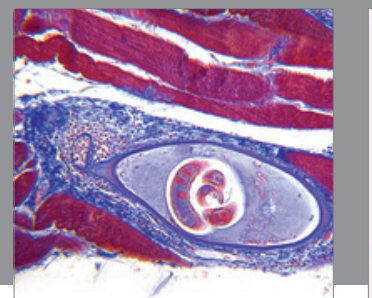

Gastroenterology

Research and Practice
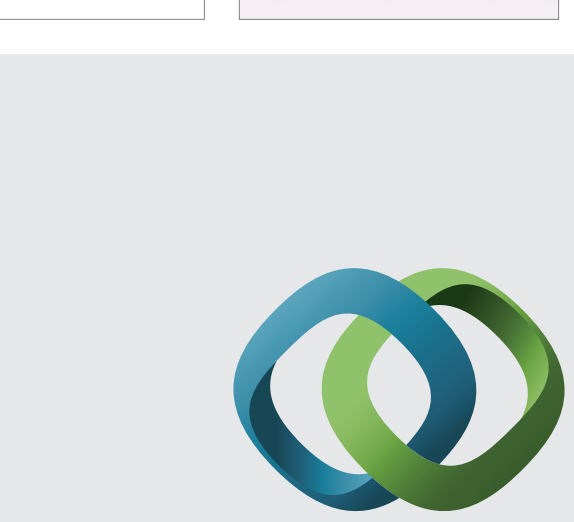

\section{Hindawi}

Submit your manuscripts at

http://www.hindawi.com
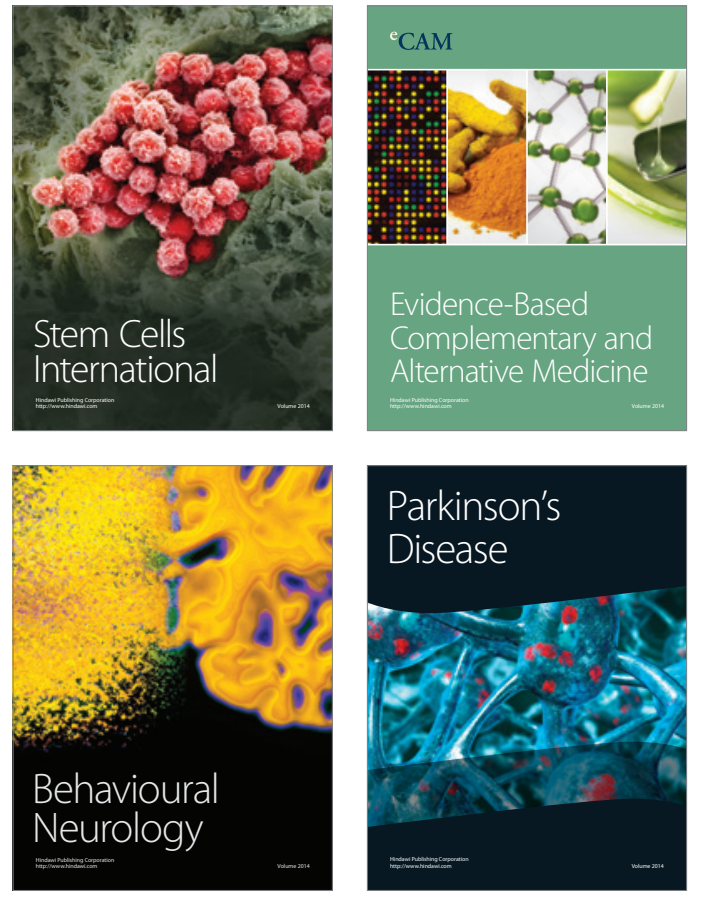
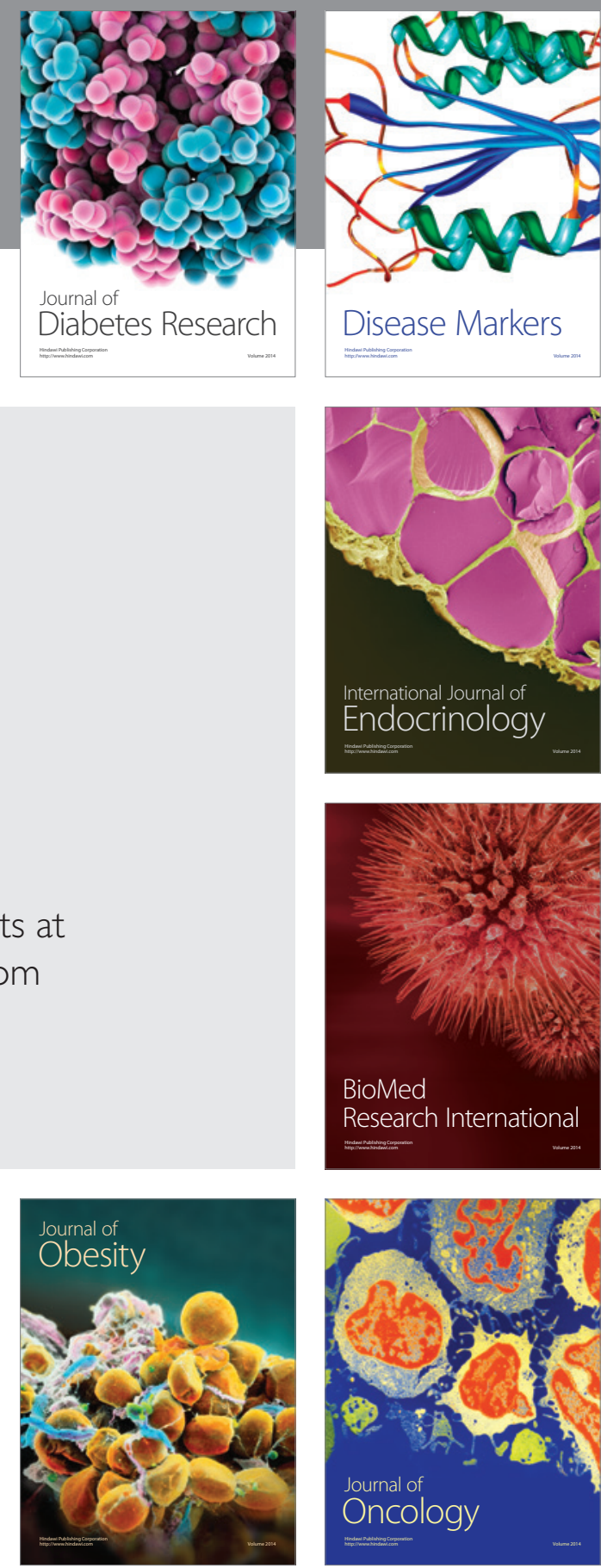

Disease Markers
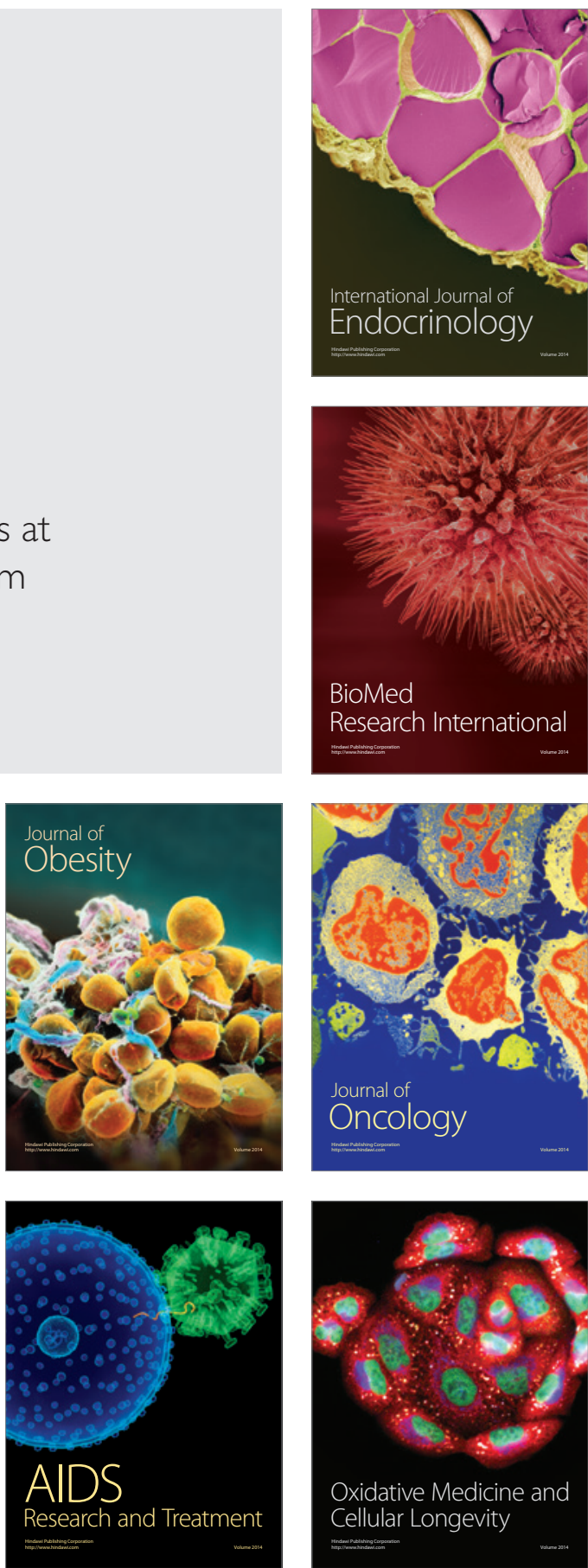